\title{
Understanding Tax Morale of Micro, Small, and Medium Enterprises in Jabodetabek
}

\author{
Benny Irawan ${ }^{1}$, Khoirunurrofik Khoirunurrofik $^{* 2}$ \\ ${ }^{1}$ Master Program of Economic Planning and Public Policy, Department of Economics, Faculty of Economics and \\ Business, Universitas Indonesia \\ ${ }^{2}$ Institute for Economic and Social Research (LPEM) and Department of Economics, Faculty of Economics and \\ Business, Universitas Indonesia \\ ${ }^{*}$ Corresponding author. Email: khoirunurrofik@ui.ac.id
}

\begin{abstract}
This study aims to identify the factors determining the tax morale of Micro, Small, and Medium Enterprises (MSME). The study is pertinent because MSME account for $60 \%$ of Indonesia's GDP yet they contribute only $0.67 \%$ to tax revenue. One reason for this low level of tax revenue is low tax morale. Tax morale refers to the intrinsic motivation of taxpayers with regard to paying taxes. The population in the research is MSME in Jakarta, Bogor, Depok, Tangerang, and Bekasi (Jabodetabek). Multistage sampling is used as the sampling technique. A total of 217 nonagricultural-sector MSME participated in this study. The results of the Structural Equation Modeling (SEM) analysis, which incorporated the SmartPLS program, show that sentiments toward tax, trust in the tax authority, perception of public goods, and attitude toward punishment positively affect the tax morale of MSME in Jabodetabek and will play a role in influencing the willingness of taxpayers to pay.
\end{abstract}

Keywords: Tax Morale, Tax Compliance, MSME, SEM

\section{INTRODUCTION}

When compared with other countries, the tax ratio in Indonesia is lower than that of several ASEAN countries and the average of OECD countries. In contrast, based on size, Indonesia's GDP ranks sixteenth in the world, fifth in Asia, and the highest in the ASEAN region (CNBC Indonesia, 2018). The low level of tax ratio is attributable to the country's relatively small tax base and its economic system that continues to be reliant on commodities and concentrates on certain taxpayers only. Nevertheless, certain sectors have great potential to increase tax revenue, including the Micro, Small, and Medium Enterprises (MSME) sector. While this sector accounts for $60 \%$ of the total GDP according to the prevailing price in 2016 (Ministry of Industry, 2016), it contributes only $0.67 \%$ of the total tax revenue (Directorate General of Taxes, 2019). The difference indicates that the level of tax compliance of MSME remains low.

The degree of tax compliance is affected by both economic and attitudinal factors (James \& Alley, 2002). The economic approach regards humans as logical beings who will always act with a certain consideration in order to obtain maximum utility from the resources they possess (Allingham \& Sandmo, 1972). The attitudinal approach, in contrast, believes that an individual is not only independent, selfish, and maximizes utility, but s/he also interacts with other individuals according to different norms, beliefs, attitudes, and roles (James \& Alley, 2002).

The economic approach is not flawless; indeed, it disregards psychological factors and is based only on economic motives. Various empirical studies have demonstrated that the economic approach (comprising the tax rate, audit, and sanctions), as offered by Allingham and Sandmo (1972), cannot be fully proved. Friedland (1982), for instance, identified that heavy sanctions cannot guarantee a level of compliance compared to light sanctions. Feld and Frey (2003) described how tax compliance is determined by a "psychological contract" between the taxpayer and the tax authority. In this psychological contract, the interaction between the incentive and intrinsic motivation to pay the tax also needs to be taken into account. 
This becomes a trigger for the government to consider the attitudinal factor when designing fiscal policy. One of the attitudinal factors that can explain taxpayer compliance is tax morale. Tax morale is usually regarded as an intrinsic motivation to comply with and pay tax, so that it contributes to social prosperity (Torgler \& Schneider, 2005).

This study is conducted to investigate the determining factors of MSME' tax morale. The focus of the research includes MSME outside the agricultural sector owing to the potential for tax revenue to be increased in this nonagricultural MSME sector compared to the agricultural sector, where roles are limited to tax revenue due to the VAT-exempt facility. The study was conducted in the Jakarta, Bogor, Depok, Tangerang, and Bekasi areas (Jabodetabek) as these regions comprise a heterogeneous society and are well known as the center of economic affairs that is supported by secondary and tertiary sectors. We expect that revealing the characteristics and behavior of MSME in Jabodetabek will also serve as a partial indication of the behavior of MSME in other regions of Indonesia.

Relatively few research studies related to the tax morale of MSME in Indonesia have been conducted. In previous studies, the concept of tax morale was measured using a single indicator, thus giving rise to concerns regarding their validity and reliability. Alm Table 1. Classification of MSME. and Torgler (2006) recommended the use of several indicators when measuring tax morale. This research takes tax morale as a latent variable, meaning that, to assess it, we need to incorporate several indicators. The method used is Structural Equation Modeling (SEM). This study builds on previous ones through the inclusion of additional exogenous variables as the determining factor of MSME' tax morale.

The current research on tax morale is expected to contribute to the literature on tax morale and the tax compliance of MSME in Indonesia. In addition, the authors hope that this study will enrich the references for policymakers in formulating tax policy.

\section{LITERATURE REVIEW HYPOTHESIS DEVELOPMENT}

\subsection{Micro, Small and Medium Enterprises}

Act No. 20 Year 2008 regarding MSME relates to productive businesses engaged in by individual persons or business entities with maximum net assets of Rp. 50 million per year. The criteria or definition of MSME in Indonesia within this study are differentiated based on the amount of net assets and annual sales proceeds. Table 1 contains the classification of MSME.

\begin{tabular}{|l|l|l|}
\hline Classification & $\begin{array}{l}\text { Net Assets } \\
\text { (exclude land \& building) }\end{array}$ & Annual Sales \\
\hline Micro & Less than IDR50 million & Less than IDR300 million \\
\hline Small & IDR50-500 million & IDR300 million-2.5 billion \\
\hline Medium & IDR500 million-10 billion & IDR 2.5 billion-50 billion \\
\hline Large & More than IDR10 billion & More than IDR 50 billion \\
\hline
\end{tabular}

\subsection{Tax Compliance}

Compliance, as defined by Roth, Scholz, and Witte (1989), occurs when taxpayers submit their tax report in due time and accurately report it according to the regulation and stipulation of the valid court. Kirchler, Hoelzl, and Wahl (2008) introduced the slippery slope framework as an approach to compliance and divided compliance into two types: enforced compliance and voluntary compliance. Enforced compliance results from the existence of a power of authority, while voluntary compliance is dependent on the trust placed in the tax authority by the taxpayer.

Related to the slippery slope framework, there are two main paradigms that are capable of explaining tax compliance: the neo-classical economic model and the behavioral economic model. The neo-classical economic model is also known as deterrence and was frequently cited in Becker's (1968) research about economics of crime. Becker suggested that punishable threats are significant for reducing illegal behavior, including acts such as traffic rules violation, vandalism, attacks, robbery, murder, and tax avoidance.

Becker's idea was adopted by Allingham and Sandmo (1972) in their theoretical analysis related to tax evasion, which assumed that a taxpayer's decision to engage in tax evasion would be based on their own calculation of whether they would attain a better financial condition. The variables used to model Allingham and Sandmo's (1972) compliance were the tax rate, the possibility of being audited (detected), and penalty. The model highlights deterrence and thus focused on tax evasion or noncompliance. 
The neo-classical economic model portrays the type of decision-making associated with human behavior in too simplistic a way. The model also excessively highlights the upholding effect of taxpayers' behavior. Empirical evidence shows that taxpayers' behavior is influenced by certain other variables, including psychological, social, political, and morale factors that were excluded from the preventive model (Bosco \& Mittone, 1997).

Significant human resources are required to increase enforced compliance, in addition to it incurring a high level of costs (Slemrod, 1992). The problem with enforced compliance is that it is not possible for the tax authority to audit all taxpayers. Arnold (2012), for example, noted that a large amount of tax is overlooked by tax officials due to the lack of any systematic approach to assessing business actors.

We should note that the taxpayer is triggered not only by audit risks and the fear of sanctions being imposed by the tax authority (Allingham \& Sandmo, 1972). There are also other dimensions that can compel an individual to meet his/her tax obligation. Previous studies have shown that various other factors also play a part, including "intrinsic motivation to pay the tax," or tax morale (Devos, 2014; Torgler, 2007).

Torgler (2006) observed that the focus of studies on tax compliance has gradually shifted as recent researchers have explored the issue of "why many people pay the tax" instead of "why people avoid tax." This shift in focus is linked to the fact that, even if the likelihood of avoiding tax exists, there are nevertheless more taxpayers who do comply. As a result, there is an urgent need to determine what drives taxpayers to comply even if it is possible to avoid tax. The new focus recommends scrutinizing tax compliance behavior. By exploring this behavior, tax morale is identified as the main variable that significantly influences taxpayers.

\subsection{MSME' Tax Compliance}

The compliance model provides a structured way of understanding and improving tax compliance. This helps us understand the determinants of taxpayer behavior and apply the most appropriate compliance strategy. Compliance behavior is determined by many factors; business, industry, sociology, economics, and psychology. In this study the compliance of MSME can be explained by the attitude to comply pyramid developed by the Australian Taxation Office. There are four levels of compliance: the disengaged, resisters, triers, and supporters.

\subsubsection{The Disenganged}

Located at the top of the pyramid, this group includes those who have decided not to comply. People with this attitude deliberately avoid their responsibilities or opt out of the tax system. Negative sentiment about the taxation system is usually offset by negative sentiment related to the role of government. The strategy to be implemented is to provide this group with a deterrent effect, through full law enforcement.

\subsubsection{Resister}

At the second level of the pyramid, this group contains those who choose not to comply but who will comply if convinced that the authorities are paying attention to them. The strategy that can be carried out is prevention through early detection of trends in tax avoidance.

\subsubsection{Tries}

Comprising the third level of the pyramid, this group contains those who are essentially willing to comply but who have difficulty in doing so and do not always succeed. They may have difficulty understanding or fulfilling their obligations, but they expect trust and cooperation to prevail in any dispute. The strategy for this group is to provide assistance and convenience in order to comply with the provisions.

\subsubsection{Supporters}

Forming the base of the pyramid, this group contains those who are willing to do the right thing. There is a commitment to support and accept the system. There is legitimate acceptance of the role of tax officers and a belief that they are fundamentally trustworthy. Efforts to improve compliance are carried out by providing convenience.

Based on the attitude to comply pyramid, and according to a review by the Fiscal Policy Agency, MSME tend to be found in the Triers and Supporters groups. They are groups that have a lack of understanding and an inability to comply with applicable regulations.

\subsection{The Concept of Tax Morale}

Tax morale, as one of the elements discussed in psychological research, is believed to affect the attitude of the taxpayer toward tax compliance (Devos, 2014; 
Torgler, 2007). Studies on tax morale were first conducted in the 1990s (Torgler, 2003). The concept was initially revealed by McClelland and Schulze (1992), who admitted the shortcoming of neo-classical economic theory and recommended widening its scope to better explain the variety of behavior in tax compliance. Tax morale has since been defined by a number of authors, but the most cited definition is from Torgler (2003): "the intrinsic motivation to pay the tax."

The level of tax compliance can be explained by tax morale (Torgler, 2007). However, despite the abundance of literature on tax morale, there is no concrete consensus with regard to its determinants. Tax morale as a concept is often not clearly defined, and there are also varied measurements and explanations as to how it works (Kirchler, 2007). Despite recognizing other factors that are relevant to tax morale, this study focuses on related factors within the context of Indonesia as a developing country.

\section{RESEARCH METHODS}

\subsection{Data and Sampling Method}

The analysis unit of this study is MSME from sectors other than agriculture, livestock, forestry, and

Table 2. List of Variables. fishery. MSME are dominant in terms of the number of establishments, accounting for 26.71 million establishments, or 99.87 percent of the total number of establishments.

The sample used in this study comprises 217 respondents, owners or managers in order to ensure that the respondents were in a position exercising authority or influence over the marketing decisions. The sampling technique used was multistage sampling by combining cluster random sampling with quota sampling. Quota sampling, which is a nonprobability method, was used because there are several conditions that either practically or theoretically does not allow random sampling to be conducted (Scheaffer et al., 2006). Therefore, it was necessary to use an alternative nonprobability form of sampling. This limitation is due to the absence of a sampling frame, namely MSME data for each subdistrict or village.

\subsection{Variabel}

There are eight independent variables used to model tax morale. These variables are taken from several studies related to moral tax that have been done before (Table II).

\begin{tabular}{|l|l|}
\hline Variable & References \\
\hline Trust in tax authority & Feld \& Frey, 2002 \\
\hline Trust in government & Torgler, 2003; Torgler \& Schneider, 2006 \\
\hline Attitude toward punishment & Fischer, Wartick, \& Mark, 1992 \\
\hline Fairness & Torgler, 2007 \\
\hline Sentiment toward tax & Torgler, 2007 \\
\hline Perception of public goods & Torgler, 2003; Morelo \& Pujol, 2012; Alm, McClelland, \& Schulze, 1992 \\
\hline Perception of legal system & Torgler, 2003; Torgler, 2004; Torgler \& Schneider, 2006 \\
\hline Perception of democracy & Torgler, 2002; Torgler, 2004; Torgler, 2005 \\
\hline
\end{tabular}

\subsection{Method of Analysis}

Bentler (1983) stated that SEM is a statistical methodology that incorporates the confirmatory approach in its hypothetical test toward multivariate analysis on a structural theory that is based on certain symptoms. This theory typically exposes a causal process that results in observation based on several variables.
There are two types of approaches to SEM: Covariance-based SEM (CB-SEM) and Partial Least Squares SEM (PLS-SEM). Hair et al. (2009) outlined a set of practical rules for choosing between CB-SEM and PLS-SEM. CB-SEM is relatively restrictive because it needs observable variables that are distributed normally. CB-SEM also assumes normality of distribution for the observable variables and needs myriad samples. PLSSEM, on the other hand, is the best alternative when the observable variables are not normally distributed and 
should be chosen if we have relatively few samples. This research incorporates the Partial Least Squares (PLS) SEM developed by Wold (1974). The approach is effective to overcome the obstacles in making and predicting the parameter in the model of the study. Because PLS does not require any assumption with regard to the certain distribution of parameter estimation, no parametric techniques for examining or evaluating the significance are needed (Chin, 1998).

\subsection{Endogeneity issue}

Problems concerning endogeneity can arise in the research model, mainly for two reasons: (1) there are some omitted variables that might also be involved in relationships that are hypothesized or controlled in the model (Antonakis et al., 2010), and (2) we expect one or more relationships (i.e., simultaneous/inverse causality) between several constructs included in the model (Abdallah, Goergen, \& O'Sullivan, 2015). As a limitation, this study has no endogeneity checks that were carried out. Benitez, Henseler, and Roldán (2016), state that until now there has not been a clear understanding of the problem or practical guidelines related to how to overcome endogeneity in research using PLS. Besides this, no PLS software package contains a test of the ability to see endogeneity (Benitez et al., 2016).

\section{RESULTS AND DISCUSSION}

\subsection{Descriptive Statistics}

Table 3. Demographic Characteristics.

\begin{tabular}{|c|c|c|c|c|c|}
\hline & MSME & & Micro & Small & Medium \\
\hline Classification & Frequency & Percent & Percent & Percent & Percent \\
\hline Micro & 175 & $80.65 \%$ & & & \\
\hline Small & 29 & $13.36 \%$ & & & \\
\hline Medium & 13 & $5.99 \%$ & & & \\
\hline Gender & & & & & \\
\hline Male & 111 & $51.15 \%$ & $50.86 \%$ & $58.62 \%$ & $38.46 \%$ \\
\hline Female & 106 & $48.85 \%$ & $49.14 \%$ & $41.38 \%$ & $61.54 \%$ \\
\hline Age group & & & & & \\
\hline 15-31 & 61 & $28.11 \%$ & $29.14 \%$ & $20.69 \%$ & $7.69 \%$ \\
\hline $31-40$ & 83 & $38.25 \%$ & $38.86 \%$ & $41.38 \%$ & $23.08 \%$ \\
\hline $41-50$ & 47 & $21.66 \%$ & $22.29 \%$ & $20.69 \%$ & $15.38 \%$ \\
\hline $51-60$ & 23 & $10.60 \%$ & $8.00 \%$ & $17.24 \%$ & $53.85 \%$ \\
\hline$>60$ & 3 & $1.38 \%$ & $1.71 \%$ & - & - \\
\hline Education level & & & & & \\
\hline Did not complete primary education & 1 & $0.46 \%$ & $0.57 \%$ & - & - \\
\hline Primary education & 16 & $7.37 \%$ & $8.00 \%$ & $6.90 \%$ & - \\
\hline Junior secondary & 25 & $11.52 \%$ & $13.71 \%$ & $3.45 \%$ & - \\
\hline Senior secondary education & 84 & $38.52 \%$ & $41.14 \%$ & $27.59 \%$ & $23.08 \%$ \\
\hline Diploma or equivalent & 28 & $13.36 \%$ & $14.29 \%$ & $10.34 \%$ & $7.69 \%$ \\
\hline Bachelor or equivalent & 44 & $20.28 \%$ & $14.29 \%$ & $37.93 \%$ & $61.54 \%$ \\
\hline
\end{tabular}




\begin{tabular}{|l|l|l|l|l|l|}
\hline & \multicolumn{2}{|l|}{ MSME } & Micro & Small & Medium \\
\hline Master or Doctoral & 19 & $8.76 \%$ & $8.00 \%$ & $13.79 \%$ & $7.69 \%$ \\
\hline Industrial categories & & & & & \\
\hline $\begin{array}{l}\text { Wholesale and retail trade; } \\
\text { repair of motor vehicles and motorcycles }\end{array}$ & 73 & $33.64 \%$ & $32.57 \%$ & $31.03 \%$ & $53.85 \%$ \\
\hline Accommodation and food service activities. & 66 & $30.41 \%$ & $35.43 \%$ & $13.79 \%$ & - \\
\hline Other service activities & 56 & $25.81 \%$ & $27.43 \%$ & $24.14 \%$ & $7.69 \%$ \\
\hline Manufacturing & 11 & $5.07 \%$ & $1.71 \%$ & $24.14 \%$ & $7.69 \%$ \\
\hline Others & 11 & $5.07 \%$ & $2.86 \%$ & $6.90 \%$ & $30.77 \%$ \\
\hline
\end{tabular}

Table III shows the details of the percentages for the main demographic characteristics that consist of sex, age group, education level, and business classification. There is not a large gap between the number of male and female respondents, accounting for 51 and 49 percent of the respondents, respectively. This indicates that women also play a significant part in the role of MSME in driving the economy. Age group shows that the majority of respondents are youth, with 66.36 percent below 40 years of age. The education background of MSME is quite good, with more than 80 percent of the practitioners graduating high school and higher education.

MSME in Jabodetabek are spread across all types of industrial categories. The majority is engaged in the wholesale and retail trade sectors; repair of motor vehicles and motorcycles, and accommodation and food service activities. The number of businesses in these two sectors dominates the number of MSME, reaching 60 percent of the nonagricultural sector. The large number of Jabodetabek residents creates a high level of consumption, thus pushing these two sectors to become the main pillars of the economy in Jabodetabek.

There are also differences in characteristics between the MSME, notably with regard to the age group, education level, and industrial categories. Most micro and small establishments are under 40 years old, while medium establishments are dominated by the age group 51-60 years. Meanwhile, based on the industrial categories, the micro establishments, at most, are dominated by types of accommodation and food service activities, while small and medium establishments are dominated by the wholesale and retail trade; and repair of motor vehicles and motorcycles. In terms of education level, there is a tendency for larger scale businesses to be run by business actors with higher levels of education.

\subsection{The Analysis of Structural Equation Model}

This study incorporates SEM analysis to observe the determining factors of tax morale among MSME in Jabodetabek. In assessing the model, the research adopts a two-step SEM approach, as recommended by Hair et al. (2009). The first step assesses the measurement model for validity and reliability. The structural equation model is assessed after the measurement model has successfully met all conditions for validity and reliability.

The SEM results in Figure 1 confirm the causal pathtoward the statistically significant tax morale of several independent constructs, including sentiments toward tax, trust in the tax authority, and the attitude toward punishment. Sentiment shows a substantial path coefficient against tax morale of 0.292. Other path coefficients such as trust in the tax authority (0.155), perception of public goods (0.153), and attitude toward punishment (0.129) have a moderate relation with tax morale. All of the path coefficients have a positive effect at the significance level of 0.10 . The tax morale variable is thus significant with regard to tax compliance.

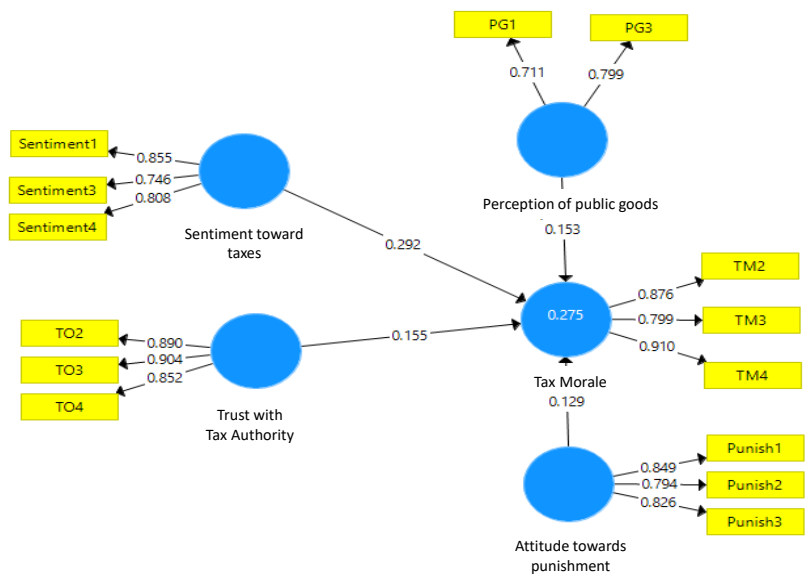

Figure 1 Structural equation model For MSME. 


\subsubsection{Trust in Tax Authorities and Tax Morale}

In this study, the relationship between taxpayers and tax authorities is believed to positively influence the desire to pay taxes. The results of this study are in line with the research of Feld and Frey (2002). Their research on taxpayers in Swiss Cantons showed that tax morale is not instinctively present in someone but rather is dependent on interaction with the tax authorities, on the legal framework, and on the constitutional environment.

\subsubsection{Trust in Government and Tax Morale}

Furthermore, from the analysis results, it can be seen that trust in the government does not affect tax morale. MSME in Jabodetabek regard having greater trust in the tax authority as more important for growing tax morale than trusting the government. This result differs from those of Torgler (2004) and Torgler (2007). Studies conducted in various countries including European countries (Belgium, Poland, Spain, and Switzerland), transition countries (Russia, Estonia, Latvia, Lithuania, Belarus and Bulgaria) and Asian countries (for example, India) show that trust in the government has a positive relationship with tax morale.

\subsubsection{Attitude Toward Punishment and Tax Morale}

The attitude toward punishment positively and significantly affects the morale of MSME in Jabodetabek. Fear of punishment is one reason taxpayers pay their taxes. Most taxpayers agree that they pay because they do not wish to be punished, or audited, or because avoidance can damage their reputation. This result is in line with Fischer, Wartick, and Mark (1992) who included attitudes toward punishment in their research as they were considered to be one of the tax compliance factors in the socio-psychological model. Punishment in this context includes the possibility of audit and penalty. In general, punishment is considered to hinder tax evasion, especially the possibility of an audit. This finding shows that deterrence plays an important role in shaping taxpayer attitudes, which ultimately affects their compliance.

\subsubsection{Fairness and Tax Morale}

The results of the SEM analysis show that tax fairness does not affect tax morale. These results are not in line with Torgler's (2007) research. If we look at the benefits principle and ability to pay, the tax regulations for MSME currently contain discriminatory tendencies and are more profitable for MSME through the provision of special tariff facilities for MSME players.

\subsubsection{Sentiment Toward Tax and Tax Morale}

Sentiment toward taxes is positively and significantly related to tax morale. This means that MSME players in Jabodetabek consider that tax sentiments will determine their tax morale. This finding supports the research of Torgler (2007) who found that tax sentiment determines tax compliance behavior.

\subsubsection{Perception of Public Goods and Tax Morale}

The other results state that perception of public goods positively and significantly affects tax morale. This reinforces the research of Alm, McClelland, and Schulze (1992) who found that people pay taxes not only because of deterrence factors (audit, sanction, and penalty) but also because "they value public goods financed by their taxes." Taxpayers tend to obey the rules set when the services they receive from the government are considered comparable to the taxes they pay (Torgler, 2003).

\subsubsection{Perception of Legal System and Tax Morale}

Perception of the legal system does not determine the tax morale of SMEs in Jabodetabek. This is because high school is the predominant level of education attained by the majority of MSME in Jabodetabek, potentially affecting the low level of legal literacy of MSME. As such, the existence of a properly functioning legal system accompanied by positive actions by the institution will not affect the tax morale of MSME. These results contradict the research of Torgler (2004) and Torgler and Schneider (2006), who concluded that the legal system is one of the institutional factors determining tax morale.

\subsubsection{Perception of Democracy and Tax Morale}

In some previous studies, perceptions of democracy were believed to determine tax morale. One such study was by Torgler (2005), who found a positive relationship between perceptions of democracy and tax morale. However, the results of this study state that perceptions of democracy are not significant, even though democracy allows people to argue and influence tax law. This is closely related to the low level of legal literacy of MSME. The perception of democracy does not therefore determine the tax morale of MSME in Jabodetabek.

Furthermore, SEM analysis was conducted on two groups; micro-enterprises and small and medium-sized enterprises. The sentiments towards taxation and attitudes towards punishment apparently determine the tax morale of micro-establisments and small and medium-establishments. An interesting point to note is 
that trust in the tax authority is significant with regard to the tax morale of micro-enterprises, while in small and medium-establishments it is not significant regarding tax morale. This is related to the cost of tax compliance. Weichenrieder (2007) stated that micro-establishments bear higher costs of compliance than small and mediumestablishments. Because micro-establishments bear higher compliance costs, they will demand more services and performance from the tax authorities. This is the reason why trust in the tax authority influences the intrinsic motivation of micro-establishments enterprises in paying taxes.

\section{CONCLUSION AND IMPLICATIONS}

This study has revealed that the tax morale of MSME in Jabodetabek positively affects tax compliance. The factors affecting tax morale of MSME in Jabodetabek are attitude toward punishment, trust in the tax authority, sentiments toward tax, and perception of public goods. All of the significant path coefficients display a positive sign, with sentiments toward tax being revealed as the most substantial path coefficient.

The sentiments towards taxation and attitudes towards punishment apparently determine the tax morale of micro-establishments and small and mediumestablishments. An interesting point to note is that trust in the tax authority is significant with regard to the tax morale of micro-enterprises, while in small and medium-establishments it is not significant regarding tax morale.

The sentiment of taxpayers plays a role in influencing the willingness of taxpayers to pay. Therefore, the main recommendation based on these findings is to increase the delivery of information about taxes and its benefits to the public. This approach should not be adopted solely by the tax authority but also by other institutions that benefit from the tax in their operations. However, this step requires an extensive and sustainable campaign. Explaining and showing how tax money is spent in order to benefit the public can increase the sentiments of the taxpayer; thus, enlightening society to pay tax will increase the amount of tax being paid.

Another effort is the government should provide support to MSMEs. Careful design of government programs for SMEs, including special tax rules, can address market failures and the disproportionately high compliance burdens faced by SMEs. Consideration of the heterogeneity of the SME sector and the different challenges faced by SMEs and their owners need to be considered in the design of the taxation rules as governments endeavor to promote the creation, innovation and growth of SMEs.

\section{RESEARCH LIMITATIONS}

This research views compliance from a psychological approach. It would be more comprehensive if further research were carried out with a fiscal psychological approach, which is a combination of an economic approach and a psychological/attitude approach. Furthermore, the sampling method in this study was multistage sampling, but the sampling unit at the last stage was quota sampling because researchers did not have a sampling frame (list of MSME per village). The use of the quota sampling, which is a nonrandom sampling, is feared to cause potential representation of characteristics per region not optimal.

\section{ACKNOWLEDGMENTS}

The authors are grateful for the support of PITMA Grant-Universitas Indonesia and also to the anonymous reviewer(s) for their useful suggestions.

\section{REFERENCES}

[1] Abdallah, W., Goergen, M. and O'Sullivan, N. 'Endogeneity: How failure to correct for it can cause wrong inferences and some remedies'. British Journal of Management, 26(4), 2015, pp. 791-804.

[2] Allingham, M. G. and Sandmo, A. 'Income tax evasion: A theoretical analysis'. Journal of Public Economics, 1(3-4), 1972, pp. 323-338.

[3] Alm, J., McClelland, G. H. and Schulze, W. D. 'Why Do People Pay Taxes?' Journal of Public Economics, 48(1), 1992, pp. 21-38.

[4] Alm, J. and Torgler, B. 'Culture differences and tax morale in the United States and in Europe.' Journal of Economic Psychology, 27(2), 2006, pp. 224246.

[5] Arnold, J. 'Improving the tax system in Indonesia.' Paris: OECD Publishing, 2012.

[6] Becker, G. S. 'Crime and punishment: An economic approach.' The Journal of Political Economy, 76(2), 1968, pp. 169-217.

[7] Benitez, J., Henseler, J. and Roldán, J. L. 'How to address endogeneity in partial least squares path modeling.' Twenty-Second Americas Conference on Information Systems, (Tanriverdi 2005), 2016, pp. 1-10.

[8] Bentler, P. M. 'Some contributions to efficient statistics in structural models: Specification and estimation of moment structures.' Psychometrika, 48, 1983, pp. 493-517. 
[9] Bosco, L. and Mittone, L. 'Tax evasion and moral constraints: Some experimental evidence.' Kyklos, 50, 1997, pp. 297-324.

[10] Chin, W. W. 'The partial least squares approach for structural equation modeling.' In G. A. Marcouliders (Ed.), Modern methods for business research, 1998, (pp. 295-236). London: Lawrence Erlbaum Associates.

[11] Devos, K. 'Factors influencing individual taxpayer compliance behavior.' London: Springer, 2014.

[12] Feld, L. P. and Frey, B. S. 'Trust breeds trust: How taxpayers are treated.' Economics of Governance, 3(2), 2002, pp. 87-99.

[13] Feld, L. P. and Frey, B. S. 'Deterrence and tax morale: How tax administrations and taxpayers interact.' OECD Papers, 3(10), 2003, pp. 1-19.

[14] Fischer, C. M., Wartick, M. and Mark, M. 'Detection probability and taxpayer compliance: A review of the literature.' Journal of Accounting Literature, 11, 1992, pp. 1-46.

[15] Friedland, N. 'A note on tax evasion as a function of the quality of information about the magnitude and creditability of threatened fines: Some preliminary research.' Journal of Applied Social Psychology, 12(1), 1982, pp. 54-59.

[16] Hair, J. F., Black, W. C., Babin, B. J., Anderson, R. E. and Tatham, R. L. 'Multivariate data analysis.' New Jersey: Pearson, Prentice-Hall, 2009.

[17] James, S. and Alley, C. 'Tax compliance, selfassessment and tax administration.' Journal of Finance and Management in Public Services, 2(2), 2002, pp. 27-42.

[18] Kirchler, E. The economic psychology of tax behavior. New York, NY: Cambridge University Press, 2007.

[19] Kirchler, E., Hoelzl, E. and Wahl, I. 'Enforced Versus Voluntary Tax Compliance: The "Slippery Slope" Framework.' Journal of Economic Psychology 29(2), 2008, pp. 210-225.

[20] Morelo, J. C. and Pujol, F. 'Walking inside the potential tax evader's mind: Tax morale does matter.' Journal of Business Ethics, 105, 2012, pp. 151-162.
[21] Roth, J. A., Scholz, J. T. and Witte, A. D. Taxpayer compliance, Volume 1: An agenda for research. Philadelphia, PA: University of Pennsylvania Press, 1989.

[22] Scheaffer, R. L., Mendenhall, W. and Ott, R. L. Elementary survey sampling (6th ed). Belmont, CA: Duxbury Press, 2006.

[23] Slemrod, J. Why people pay taxes: Introduction. In J. Slemrod (Ed.), Why people pay taxes. Ann Arbor, MI: University of Michigan Press, 1992, pp. $1-8$.

[24] Torgler, B. 'Speaking to theorists and searching for facts: Tax morale and tax compliance in experiments.' Journal of Economic Surveys, 16(5), 2002, pp. 657-684.

[25] Torgler, B. 'Tax morale, rule-governed behavior and trust.' Constitutional Political Economy, 14(2), 2003, pp. 119-140.

[26] Torgler, B. 'Tax morale in Asian countries.' Journal of Asian Economics, 15(2), 2004, pp. 237 266.

[27] Torgler, B. 'Tax morale and direct democracy.' European Journal of Political Economy, 21(2), 2005, pp. 525-531.

[28] Torgler, B. 'The importance of faith: Tax morale and religiosity.' Journal of Economic Behavior \& Organization, 61(1), 2006, pp. 81-109.

[29] Torgler, B. Tax compliance and tax morale: A theoretical and empirical analysis. Cheltenham, UK: Edward Elgar, 2007.

[30] Torgler, B. and Schneider, F. 'Attitudes toward paying taxes in Austria: An empirical analysis.' Empirica, 32(2), 2005, pp. 231-250.

[31] Torgler, B. and Schneider, F. 'What shapes attitudes toward paying taxes? Evidence from multicultural European countries.' Social Science Quarterly, 88(2), 2006, pp. 443-470.

[32] Weichenrieder, A. J. 'Survey on the taxation of small and medium-sized enterprises.' OECD Working Paper, 25 September 2007. 